\title{
Symposium review: The choice and collection of new relevant phenotypes for fertility selection*
}

\author{
A. Fleming, ${ }^{1,2}$ † C. F. Baes, ${ }^{1}$ A. A. A. Martin, ${ }^{1,3}$ T. C. S. Chud, ${ }^{1}$ F. Malchiodi, ${ }^{1,4}$ L. F. Brito,,${ }^{1,5}$ and F. Miglior ${ }^{1,2}$ \\ ${ }^{1}$ Centre for Genetic Improvement of Livestock, Department of Animal Biosciences, University of Guelph, Guelph, ON, N1G 2W1, Canada \\ ${ }^{2}$ Canadian Dairy Network, Guelph, ON, N1K 1E5, Canada \\ ${ }^{3}$ Animal Breeding and Genomics Centre, Wageningen University and Research, Wageningen, 6708PB, the Netherlands \\ ${ }^{4}$ Semex Alliance, Guelph, ON, N1H 6J2, Canada \\ ${ }^{5}$ Department of Animal Sciences, Purdue University, West Lafayette, IN 47907
}

\section{ABSTRACT}

In dairy production, high fertility contributes to herd profitability by achieving greater production and maintaining short calving intervals. Improved management practices and genetic selection have contributed to reversing negative trends in dairy cow fertility, but further progress is still required. Phenotypes included in current genetic evaluations are largely interval and binary traits calculated from insemination and calving date records. Several indicator traits such as calving, health, variation in body condition score, and longevity traits also apply to genetic improvement of fertility. Several fertility traits are included in the selection indices of many countries, but for improved selection, the development of novel phenotypes that more closely describe the physiology of reproduction and limit management bias could be more effective. Progesteronebased phenotypes can be determined from milk samples to describe the heritable interval from calving to corpus luteum activity, as well as additional measures of cow cyclicity. A fundamental component of artificial insemination practices is the observation of estrus. Novel phenotypes collected on estrous activity could be used to select for cows clearly displaying heat, as those cows are more likely to be inseminated at the right time and therefore have greater fertility performance. On-farm technologies, including in-line milk testing and activity monitors, may allow for phenotyping novel traits on large numbers of animals. Additionally, selection for improved fertility using traditional traits could benefit from refined and accurate recording and implementation of parameters such as pregnancy confirmation

Received July 30, 2018.

Accepted December 2, 2018.

*Presented as part of the Breeding and Genetics Symposium: Fertility - Filling the Gaps, at the ADSA Annual Meeting, Knoxville, Tennessee, June 2018.

†Corresponding author: fleming@cdn.ca and reproductive management strategy, to differentiate embryonic or fetal loss, and to ensure selection for reproductive capability without producer intervention. Opportunities exist to achieve genetic improvement of reproductive efficiency in cattle using novel phenotypes, which is required for long-term sustainability of the dairy cattle population and industry.

Key words: novel fertility trait, on-farm technology, phenotyping, reproduction trait

\section{INTRODUCTION}

In dairy production, there is a strong association between a herd's reproductive performance and its profitability (De Vries, 2006). It is essential for a heifer or cow to successfully establish a sustainable pregnancy in a timely manner to minimize calving intervals, while maximizing milk production and reducing management requirements. Furthermore, optimizing cow fertility helps to achieve genetic progress in a population by reducing rates of culling due to fertility disorders or poor fertility performance and ensuring that the genetics of high-merit animals are passed to the next generation.

Continuous selection for high-producing dairy cows has been associated with deteriorating fertility in these animals (Pryce et al., 2004). Unfavorable genetic correlations have been reported between milk yield and fertility traits (Pryce et al., 1997; Dematawewa and Berger, 1998; Roxström et al., 2001a), suggesting selection for increased milk production may have contributed to declining fertility in dairy cows. Inappropriate management of these high-producing cows by not meeting increased feed, metabolic, and other management demands may also contribute to poor fertility (LeBlanc, 2010). Fertility is a complex trait, affected by the environment, management practices, and genetics, along with their interactions, which makes it difficult to discern exact mechanisms formulating its decline (Walsh et al., 2011). Management practices of a herd can have a strong influence on fertility and reproduc- 
tive outcomes, and management improvements have reversed some of the poor fertility observed on farm. These factors include improvements in heat detection and feeding, and advances in reproductive technologies, including hormonal treatment of anestrous cows. Improving and understanding the genetic components of fertility need to be prioritized to prevent genetic decline in cow fertility and generate further progress in this area.

In response to declining fertility and growing acknowledgment of additional functional traits, many countries have expanded the number of traits in their selection indices from solely production and type traits to further include traits related to fertility and health (Miglior et al., 2005, 2017). Although progress has been made in relation to fertility, substantial advancement has been hard to come by, as analyzed fertility traits generally have heritability estimates below 0.10 (Wall et al., 2003; VanRaden et al., 2004; Jamrozik et al., 2005). Commonly, female fertility traits include those measuring conception success following AI, and intervals representing reproductive rates (Wall et al., 2003), using data from insemination records, pregnancy testing, and calving dates. Some of these variables might be incomplete or less accurate depending on the production system (e.g., intensive vs. pastoral production system).

Reproductive success includes many distinctive physiological events where failures can contribute to poor fertility, which currently evaluated fertility traits fail to differentiate, as they typically measure overall reproductive success or failure. Inability to establish and maintain pregnancy could be a result of lack of estrous behavior, failure to ovulate, delayed resumption of cyclicity or inappropriate cyclicity patterns, or embryonic or fetal loss at various stages (Royal et al., 2000a; Walsh et al., 2011). Each of these stages making up female fertility consist of various biological processes or are time points at which problems contributing to subfertility can be realized. A challenge in the genetic improvement of fertility is finding relevant, easily measurable or recordable phenotypes to represent the various aspects of fertility and better describe the underlying physiology.

In the advent of data-driven and data-rich dairy production systems, the amount of information recorded on an animal through its lifetime has become extensive and far-reaching in scope. Many new data-producing technologies, directly or otherwise incidentally linked to reproductive management, have been implemented by producers to support herd management. Additionally, producers have an incentive and interest in acknowledging the declining fertility in their herds to record and accumulate additional parameters. As a result, the amount of phenotypic data with potential applications in genetic selection for various selection goals, including improved fertility, has expanded.

Here we describe the current established phenotypes and strategies for genetic improvement of fertility in dairy cattle and outline potential opportunities for novel phenotypes to better describe the intricacies of and select for fertility.

\section{CURRENT PRACTICES FOR FERTILITY SELECTION}

\section{Direct Selection on Phenotypes Describing Fertility}

The fertility traits measured in dairy cattle are strongly influenced by several factors including environmental effects, management decisions, and the cow's physiology. Some traits are also measured late in life or over long time periods (e.g., calving interval), which could increase generation interval and reduce genetic progress per time unit if accurate genomic breeding values were not available to enable early selection. The large phenotypic variance observed for reproductive traits, resulting in part from the large influence of environmental and management factors, may greatly obscure the additive genetic variation that is inferior but nonetheless present (Miglior et al., 2017). This is supported by the effectiveness of the direct selection for fertility that shows, despite the low heritability estimates observed in several studies (e.g., VanRaden et al., 2004; Veerkamp and Beerda, 2007), the existence of genetic variation among individuals (Pryce and Veerkamp, 2001).

The direct selection for fertility traits started in most countries at the beginning of the 21st century (VanRaden et al., 2003; Van Doormaal et al., 2004; Miglior et al., 2017). However, despite the recent inclusion of these traits in national selection indices, the genetic improvement of these traits using the traditional genetic evaluation has been slow over the years due to the low heritability of the traits and low reliability of estimated breeding values, and the influence of the reproductive management applied.

Traditional fertility traits used in selection programs are typically measured using time intervals (e.g., calving interval; CIN) and success or nonsuccess traits (e.g., nonreturn rate; NRR). In general, genetic evaluations to improve cow fertility have been performed with the following phenotypes: CIN, interval between calving and first insemination (ICF), interval between the first and the last insemination, NRR within a defined time period, days open (DO), and conception rate $(\mathbf{C R}$; Tables 1 and 2). In seasonal calving systems, submis- 
sion rate, describing the interval from the planned start of mating to first insemination, and calving rate from the herd's planned start of calving could be meaningful alternative traits. Pregnancy rate may be preferred over DO because it is easier to define, available sooner, and nonpregnant cows can be included in the calculation (VanRaden et al., 2004). The voluntary waiting period, or the time postpartum where a cow is deliberately not bred, also makes up part of the time considered in some interval traits. This time can vary between herds and even within a herd for different animals, owing to the strong management effect on these traits. Management issues such as heat detection, proper timing of insemination, and poor record-keeping can also affect trait measures.

The International Bull Evaluation Service Centre (Interbull, Uppsala, Sweden) introduced the international genetic evaluation service for fertility across countries in 2007 (multiple-trait across country evaluations, MACE; Schaeffer, 1994) using 5 female traits (Interbull, 2018): (1) maiden heifer's ability to conceive; (2) lactating cow's ability to recycle after calving; (3)

Table 1. Heritability estimates of fertility trait groups considered by Interbull in different countries (Interbull, 2018) ${ }^{1}$

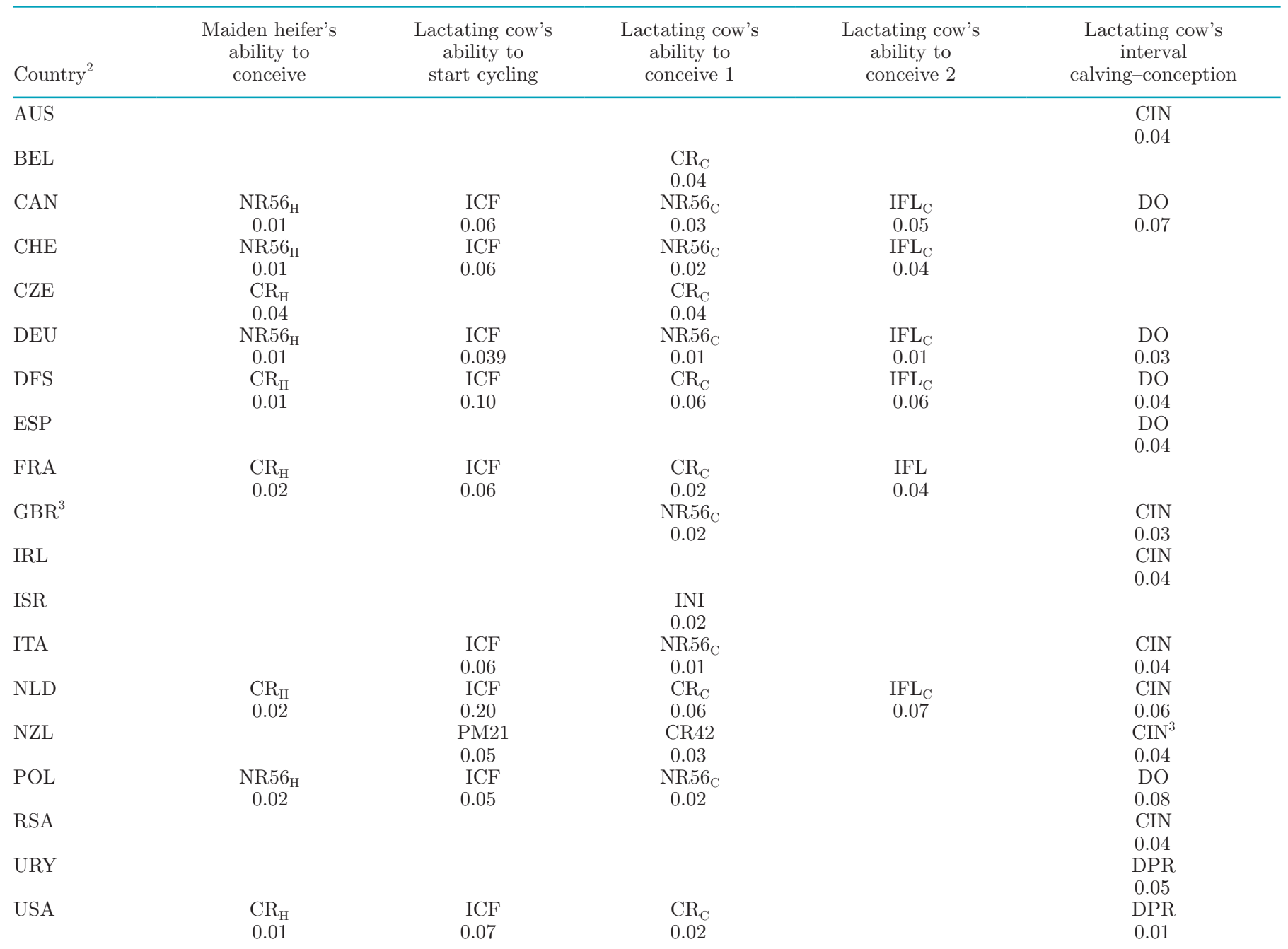

${ }^{1} \mathrm{CIN}=$ calving interval; $\mathrm{CR}=$ conception rate; NR56 = nonreturn rate at $56 \mathrm{~d} ; \mathrm{ICF}=$ days between calving and first insemination; IFL $=$ days between first insemination and conception; DO = days open, days between calving and conception; INI = inverse of the number of services; PM21 = mating in the first $21 \mathrm{~d}$ of herd's mating period; CR42 = recalving in the first $42 \mathrm{~d}$ of the herd's calving period; DPR $=$ pregnancy rate for each estrous cycle. Subscripts: $\mathrm{H}=$ heifer; $\mathrm{C}=$ cow.

${ }^{2}$ AUS $=$ Australia; BEL = Belgium; CAN = Canada; CHE = Switzerland; CZE = Czech Republic; DEU = Germany, Austria, Luxembourg; $\mathrm{DFS}=$ Denmark, Finland, Sweden; ESP $=$ Spain; FRA $=$ France; GBR = Great Britain; IRL = Ireland; ISR $=$ Israel; ITA $=$ Italy; NLD = the Netherlands; NOR $=$ Norway; NZL $=$ New Zealand; POL $=$ Poland; RSA $=$ Republic of South Africa; URY = Uruguay; USA = United States. ${ }^{3}$ Only on first lactation. 
lactating cow's ability to conceive expressed as a rate trait; (4) lactating cow's ability to conceive expressed as an interval trait; (5) lactating cow's measurements of interval traits calving-conception. The heritability estimates and the different measures considered for these traits for each Interbull-participating country are described in Table 1. The heritability estimates for the various traits are generally low, and the differences noted could be a result of differences in environment, trait definitions, evaluation model, or the records allowed for inclusion in the genetic evaluations.

In their own national selection indices, different countries have defined and emphasized fertility traits independently based on the selection criteria applied in the population (Table 2). Variation is present in the traits used, number of traits, and the final weighting of the reproduction subindex in the overall index.

The availability of genomic data, such as SNP markers and whole-genome sequence, have provided additional opportunities to improve dairy cattle fertility. Several studies identified SNP and deleterious haplotypes related to fertility and reproduction traits (VanRaden et al., 2011; Nayeri et al., 2016; ParkerGaddis et al., 2016; Müller et al., 2017). The inclusion of genomic information, such as SNP markers and variants from whole-genome sequence data, has provided better reliability estimates for fertility traits (Wiggans et al., 2011; Ortega et al., 2016; VanRaden et al., 2017). However, to increase the genetic progress for fertility it is necessary to improve the quality of phenotypes

Table 2. Relative emphasis of fertility traits in selection indices worldwide ${ }^{1}$

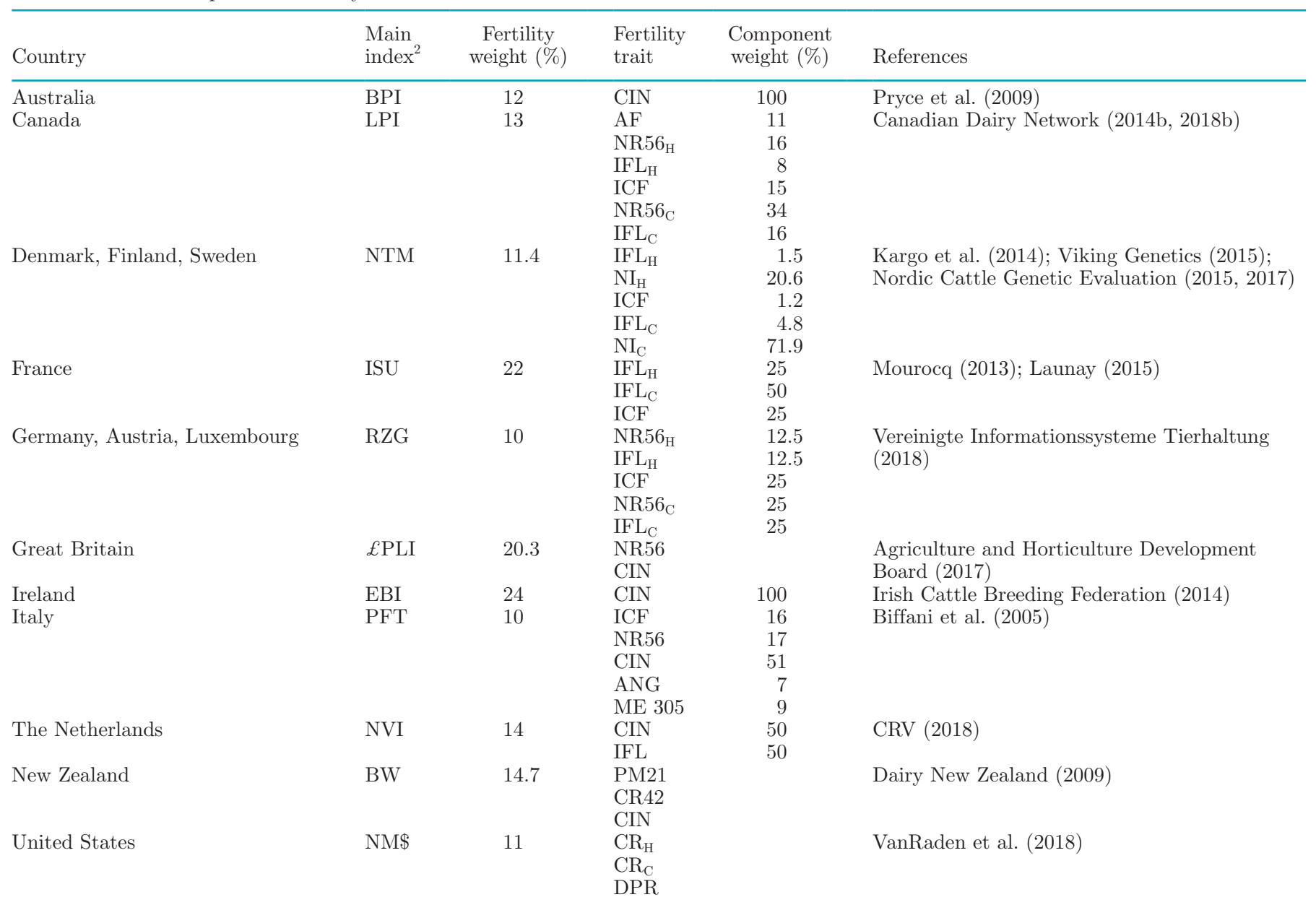

\footnotetext{
${ }^{1} \mathrm{AF}=$ age at first service; NR56 = nonreturn rate at $56 \mathrm{~d}$; ICF $=$ interval between calving and first insemination; IFL $=$ interval between first insemination and conception; $\mathrm{DO}=$ days open; $\mathrm{CIN}=$ calving interval; $\mathrm{DPR}=$ pregnancy rate for each estrous cycle; $\mathrm{NI}=$ number of inseminations; ANG = angularity; ME $305=$ mature equivalent milk yield at 305 d; PM21 = mating in the first $21 \mathrm{~d}$ of herd's mating period; CR42 = recalving in the first $42 \mathrm{~d}$ of the herd's calving period; $\mathrm{CR}=$ conception rate. Subscripts: $\mathrm{H}=$ heifer; $\mathrm{C}=$ cow.

${ }^{2} \mathrm{BPI}=$ balance performance index; LPI = lifetime performance index; NTM $=$ Nordic total merit; ISU = France total merit index; RZG $=$ German total merit index; $£$ PLI = profitable lifetime index; EBI = economic breeding index; PFT = productivity, functionality, and type; NVI $=$ Dutch-Flemish total merit index; $\mathrm{BW}=$ breeding worth; $\mathrm{NM} \$=$ net merit.
} 
and the number of records available, as well as better record-keeping of reproductive management practices. The selection for improved fertility in dairy cattle still remains a big challenge for breeders, farmers, and the industry.

\section{Indirect Selection for Improved Fertility}

The ability of a dairy cow to successfully achieve pregnancy and ultimately birth a healthy calf is reliant on various additional traits describing a robust animal in prime condition to reproduce. Some traits currently under selection in the dairy industry are favorably genetically correlated with the overall reproductive success of the cow, and thus, are contributors to the indirect genetic improvement of fertility in selection programs. Given the challenges that exist in the currently evaluated fertility phenotypes, including low heritability estimates and the appreciably broad nature of describing fertility, the introduction of fertility-correlated traits has improved cow fertility; future traits currently under investigation may help to further this cause.

As an accompaniment to the earlier mentioned fertility traits, calving traits are frequently evaluated and fit into comprehensive reproduction trait indices. Such traits evaluated in selection programs include calving ease, calf size, and stillbirth (Miglior et al., 2017). Difficult calving has been shown to have detrimental effects on the subsequent reproductive performance of the dam (Dematawewa and Berger, 1997; López de Maturana et al., 2007; Eaglen et al., 2011). In the Canadian Holstein population, Jamrozik et al. (2005) found a heritability of 0.14 for calving ease in heifers and favorable genetic correlations with fertility traits, the greatest being 0.18 with NRR. Calving difficulty can also be attributed to the service sire and this effect should also be accounted for in genetic evaluations, especially when considering that the cow and sire mated are unrelated or lowly related.

Longevity, or similarly defined traits related to the ability of or length of time a cow is able to remain in the productive herd, is routinely evaluated in many countries as a means to genetically decrease reasons for involuntary, premature culling of a cow. Infertility is a prominent reason for early disposal of an otherwise valued cow in many dairy herds. Although longevity describes a broad number of aspects, fertility is an important component favorably selected for using longevity traits. VanRaden et al. (2004) reported a genetic correlation between productive life from the United States and DO of -0.59 , indicating the major role of fertility within productive life. Similarly, Wall et al. (2003) and Sewalem et al. (2008) found favorable genetic correla- tions between fertility traits and longevity measures in the United Kingdom and Canada, respectively.

Body condition score, a subjective measure of the amount of ME reserves of a cow, can be used as an indicator of cow energy balance, health, and fertility (Roche et al., 2009). The BCS of a cow is easily recordable and can be available on all animals, and therefore is included in many national genetic evaluations. The heritability of BCS is moderate at various stages of lactation (Pryce et al., 2001; Berry et al., 2003; Loker et al., 2013), making it an attractive indicator trait to be used for selection for fertility. In general, moderate, favorable genetic correlations between BCS and fertility have been reported (Dechow et al., 2001; Pryce et al., 2001; Veerkamp et al., 2001; Bastin et al., 2010). In an extensive review, Roche et al. (2009) indicated that the association between BCS and fertility traits is generally nonlinear, and that reproductive disorders arise from having cows that are either too thin (especially in early lactation) or too fat (especially before calving), suggesting that BCS could be considered an intermediate optimum trait. The relationship between energy balance and fertility is a strong subject of interest, and additional indicator traits of energy balance that may relate to reproductive performance have been investigated, such as milk fatty acid contents (McParland et al., 2015; Bastin et al., 2016).

Various physiological issues experienced by dairy cows can affect future fertility (Walsh et al., 2011). Health traits are now frequently evaluated in dairy cattle selection programs, by way of indicator traits and more recently using clinical health information. A meta-analysis performed by Fourichon et al. (2000) reported that clinical ketosis, dystocia, retained placenta, locomotion disorders, and metritis events influenced days to first service and conception rates. Loeffler et al. (1999) and Gröhn and Rajala-Schultz (2000) also highlighted the effect of certain diseases and reproductive disorders on subsequent reproductive performance. Koeck et al. (2014) reported significant genetic correlations between retained placenta, metritis, and cystic ovaries and female fertility traits. For the single fertility diseases or disorders examined, Gernand and König (2017) estimated genetic correlations ranging from 0.10 between ICF and metritis to 0.87 for ICF and anoestria. However, like fertility traits, health traits typically have low heritability estimates (Pryce et al., 1997; Zwald et al., 2004; Koeck et al., 2012; Haugaard and Heringstad, 2015). Worldwide, health traits are still selected for, as cow health is economically important and has welfare implications. Inclusion and focus on these traits in selection can be advantageous to the improvement of fertility. 


\section{A Case Study-Canada}

The genetic evaluation for female's reproductive performance in Canada began in 2004 with the inclusion of the daughter fertility index (DF) in the national breeding program (Van Doormaal et al., 2004; Miglior, 2007). This index was originally based on 4 traits, and includes 6 traits since April 2017 (4 interval and 2 rate traits) measured in heifers and lactating cows by the following equation: $\mathrm{DF}=11 \% \mathrm{AFS}+16 \% \mathrm{NRR}_{\mathrm{H}}+$ $8 \% \mathrm{FSTC}_{\mathrm{H}}+15 \%$ CTFS $+34 \% \mathrm{NRR}_{\mathrm{C}}+16 \% \mathrm{FSTC}_{\mathrm{C}}$, where AFS is the age of the heifer at the first service, CTFS is the interval between calving and first insemination; $\mathrm{NRR}_{\mathrm{H}}$ and $\mathrm{NRR}_{\mathrm{C}}$ is the 56-d nonreturn rate for heifers and milking cows, respectively; and $\mathrm{FSTC}_{\mathrm{H}}$ and $\mathrm{FSTC}_{\mathrm{C}}$ is the interval between first insemination and conception of heifers and lactating cows, respectively.

The DF indicates the genetic potential of the sires for fertility traits considering the average of the reproductive performance of their daughters across all lactations. The insemination records provided by AI organizations and DHI have been used to evaluate the fertility traits on the DF index. Therefore, these data are very dependent on the accuracy of the dairy farmers to monitor and record reproduction events, such as to detect the correct dates of the heat and conception events. To more accurately identify conception dates, the Canadian Dairy Network is now using veterinary pregnancy confirmation data collected from multiple herds enrolled in DHI. Furthermore, a recent analysis by the Canadian Dairy Network has shown that an increasing percentage of Canadian dairy farmers are using heat synchronization protocols in their farms (Canadian Dairy Network, 2018a).

The genetic evaluation model for fertility in Canada has implemented a multi-trait animal model based on 16-trait reproductive performance (Jamrozik et al., 2005). The estimates of heritability for these traits range from 0.02 to 0.07 and for the DF index the heritability is less than $5 \%$. Although the heritability is low for DF, there is sizeable variation among proven sires. Considering the average daughter performance based on reproductive data for at least 1,000 daughters, the difference observed among the top 5 percent of sires and the bottom 5 percent of sires in the national genetic evaluation was an average of +19 points for DF, equivalent to almost 4 standard deviations (Canadian Dairy Network, 2014a).

To improve cow fertility across the herds in Canada, DF has been included into the Life Performance Index (LPI) since 2004, with increasing relative emphasis over time. Currently the relative emphasis of DF in LPI ranges between 2.0 and $6.7 \%$, varying among the dairy breeds. The relative weights for DF in this component for Holstein, Guernsey, Ayrshire, Canadienne, Brown Swiss, Jersey, and Milking Shorthorn breeds are 6.7, $6.7,5.3,5.0,4.0,3.0$, and 2.0, respectively.

Genetic progress for fertility in Canada has occurred at a slow pace. However, after the introduction of genomics in Canada in 2009, and gaining more emphasis in LPI, a faster genetic gain has been observed for fertility traits. For daughter fertility, during the first $5 \mathrm{yr}$ of the implementation of genomics (2011-2016), the genetic gain increased by $1.78 \mathrm{EBV}$ points per year (from -0.72 to +1.06 ) or 0.64 standard deviation units per year (Canadian Dairy Network, 2017). Figure 1 shows phenotypic trends for various female fertility traits in first-parity Holsteins by year of calving. Phenotypically, dairy cow fertility has improved over the years in Canada, in particular for CIN, DO, and ICF. However, the decrease of $10 \mathrm{~d}$ in $10 \mathrm{yr}$ is due to the reduction of the interval calving to first service, with no sizeable improvements in the interval first service to conception. This improvement may be due to the increasing usage of timed AI in Canada, and will be difficult to disentangle from the effective genetic progress that occurred for fertility traits. It will be a priority to keep track of which cows have been treated for timed $\mathrm{AI}$ and to include this factor in fertility evaluations in Canada and elsewhere to improve the accuracy of breeding value estimation.

\section{NOVEL FERTILITY PHENOTYPES}

Optimizing data collection and selection strategies employed for the genetic improvement of dairy cattle reproduction is of value for continued progress. Current phenotypes used in genetic evaluations may be influenced by management practices, are lowly heritable, and fail to describe intermediate events composing overall reproductive success. The incorporation of such reproduction traits into national selection indices has led to modest progress in these traits, but industry advancements could lend to additional traits that have potential to complement current traits. Many new phenotypes have been proposed to better express the underlying biology of reproduction in cattle with minimal influence of producer management decisions. As well, with emerging technologies and data sources, there are opportunities to both better characterize and improve the accuracy of current traits, and potentially collect novel phenotypes at a national level (Crowe et al., 2018; Fleming et al., 2018). There is a plethora of novel phenotypes to describe many different aspects of female reproduction in dairy cows, and here we discuss some of those most attainable for implementation. 


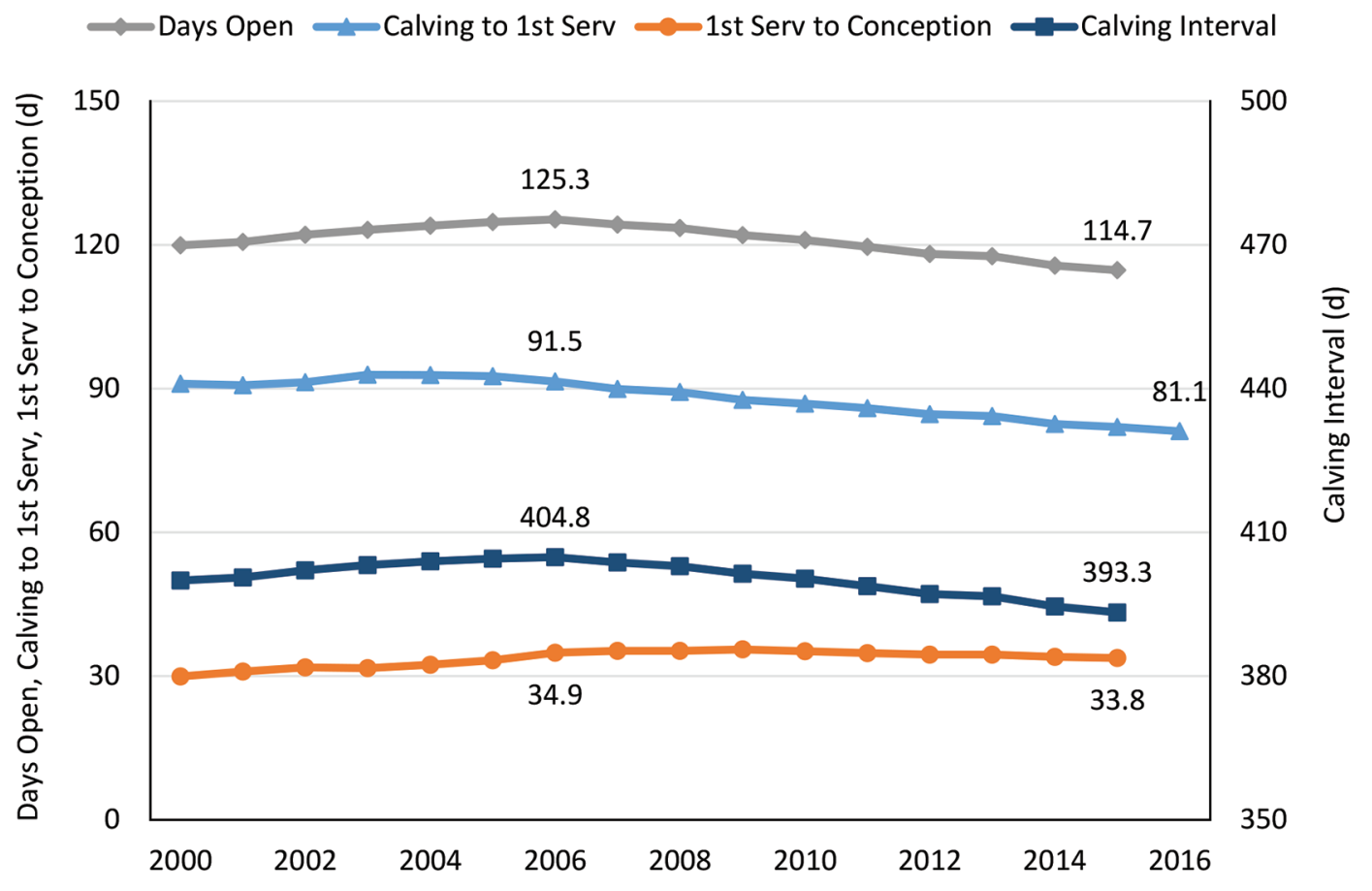

Figure 1. Phenotypic trends of fertility traits from 2000 to 2016 by year of calving for over 2.5 million first-parity Canadian Holstein cows. Serv $=$ service.

\section{Progesterone-Based Measures}

Endocrine-derived phenotypes, largely focused on milk progesterone (P4) levels, have been suggested as indicators of fertility in dairy cows as they more directly describe the physiology of the cow and are not directly influenced by producer management decisions such as insemination timing. The phenotype garnering much of the interest and research is commencement of luteal activity (C-LA), defined as the number of days postpartum to the commencement of luteal activity, as determined by a rise in $\mathrm{P} 4$ levels in milk exceeding a set threshold (e.g., $3 \mathrm{ng} / \mathrm{mL}$; Darwash et al., 1997a; Royal et al., 2000b; Petersson et al., 2007). Commencement of luteal activity has been found to have a higher heritability than traditional fertility traits, with reports of heritabilities for C-LA or transformed C-LA ranging between 0.13 and 0.28 (Darwash et al., 1997a; Veerkamp et al., 2000; Royal et al., 2002; Petersson et al., 2007; Nyman et al., 2014). Phenotypically, an early return to cyclic activity in postpartum cows has been associated with a shortened interval from calving to conception, increased CR, and fewer services per conception (Darwash et al., 1997b). Nyman et al. (2014) reported a genetic correlation of 0.35 for C-LA with ICF. Tenghe et al. (2015) estimated genetic correlations of 0.26 and 0.37 for log-transformed C-LA with CIN and ICF, respectively.
Many additional fertility phenotypes have also been derived from the same P4 measurements. Some examples are length of first luteal phase, occurrence of delayed luteolysis, proportion of samples with luteal activity, interluteal interval, prolonged luteal phase, and delayed ovulation (Royal et al., 2002; Nyman et al., 2014; Tenghe et al., 2015; Sorg et al., 2017). Nyman et al. (2014) reported a moderate heritability for delayed cyclicity (0.24) and low heritabilities for prolonged luteal phase, luteal phase length, interluteal interval, and interovulatory interval $(0.02,0.08,0.08$, and 0.03 , respectively). Sorg et al. (2017) found low heritabilities between 0.03 and 0.07 for delay to cyclicity and higher heritabilities of 0.12 to 0.23 for proportion of luteal activity between 15 and 63 d postpartum using automated on-farm ELISA test kits. There are many possible ways to describe the $\mathrm{P} 4$ profile of a cow and researchers continue to investigate optimal ways to find the most ideal traits for genetic selection.

The application of $\mathrm{P} 4$-based measures in genetic evaluations has thus far been limited by the cost and labor associated with obtaining sufficient P4 samples to generate the phenotypes on large numbers of cows. Veerkamp et al. (1998) suggested that mean P4 profiles for a group of animals may be established from samples collected during monthly milk recording. van der Lende et al. (2004) proposed a new trait, CLA50\%, identifying the stage of lactation at which $50 \%$ of test bulls' 
daughters have had an active corpus luteum, based on individual P4 measurements of daughters at 3- to 6-wk intervals. Pearson correlations between CLA50\% and EBV for the fertility index then used in the Netherlands and days to first service were -0.73 and -0.63 , respectively, but the correlation was essentially zero with NRR at 56 d (van der Lende et al., 2004). On a cow level, Petersson et al. (2007) studied the possibility of combining P4 measurements with milk recording by investigating the effect of different sampling intervals. For the percentage of samples with luteal activity during the first $60 \mathrm{~d}$ postpartum (PLA), they found that their initial heritability estimate of 0.30 when all samples were used decreased to $0.25,0.20$, and 0.14 for weekly, twice-monthly, and monthly sampling, respectively. Genetic correlations for monthly sampling PLA was -1 with transformed C-LA and -0.53 with delayed ovulation, comparable to other sampling intervals, but genetic correlations with interval from calving to first AI, persistent corpus luteum, and milk yield $56 \mathrm{~d}$ postpartum were not similar to those for other sampling intervals (Petersson et al., 2007). Still, the authors summarized that monthly P4 sampling would be sufficient to accurately predict EBV for commencement of luteal activity.

Advancing on-farm technologies may produce data useful in the genetic evaluation of $\mathrm{P} 4$ reproduction traits. Technologies have advanced to allow in-line systems to instantly measure P4 levels in milk (Friggens et al., 2008). Herd Navigator (DeLaval International, Tumba, Sweden) is a commercially available management tool for dairy producers that automatically samples and analyzes milk for several milk constituents including P4 during milking. Using P4 levels from the Herd Navigator, Tenghe et al. (2015) reported a heritability estimate of 0.12 for both transformed C-LA and PLA, which had a genetic correlation of -0.91 with each other. The genetic correlation for transformed C-LA with CIN and ICF were 0.26 and 0.37 , respectively, with similar but opposite direction correlations for PLA with the same traditional fertility. However, correlations had high standard errors associated with them, likely due to the small number of herds analyzed. Also using Herd Navigator data, Häggman et al. (2018) reported higher heritabilities for C-LA and calving to the first heat identified by Herd Navigator at 0.24 to 0.32 and 0.19 to 0.33 , respectively. At present, few herds have in-line systems capable of measuring $\mathrm{P} 4$, as these systems still have a high cost. Findings to date demonstrate that this data source can be used to define and investigate $\mathrm{P} 4$ reproductive phenotypes, which could be advantageous in genetic selection for improved fertility in the future.
Currently, there is no clear agreed best practice for defining and measuring C-LA for selection programs with many studies using different methods to determine $\mathrm{P} 4$, sampling intervals, thresholds for $\mathrm{P} 4$, and algorithms to determine traits. The reported parameters do still signify that there is genetic variation to exploit within C-LA. Therefore, C-LA, as well as similar endocrine phenotypes, are promising for genetic selection for improved fertility as their collection increases, but more research is required to ascertain their utility and value to breeding programs.

\section{Estrous Expression and Activity Traits}

Many reproductive management strategies rely on estrous behavioral signs to predict time of ovulation and the optimal insemination time. Difficulties in detecting estrus on-farm may include anovulation, silent ovulations, or few cows expressing standing estrus (Roelofs et al., 2005; Palmer et al., 2010; Fricke et al., 2014). Failure to show or detect estrus can limit the rate that cows become pregnant and results in longer calving intervals. Assessing the ability and strength of estrous expression in dairy cows could improve reproductive efficiency.

Subjective measures of strength of estrous expression have been investigated as potential traits. In Sweden, scores for heat symptoms at each insemination are included in the extensive list of data recorded. Roxström et al. (2001b) examined heat intensity scored by inseminators and farmers as weak, normal, or strong, and reported heritabilities ranging from approximately 0.01 to 0.03 . The low heritability offers little utility of the subjective scoring of heat intensity in genetic selection.

There is a trend toward the uptake of new technologies by dairy producers for detecting estrus that accurately identify individual cows by continuous monitoring with minimal labor involved. Such farm management systems, together with sensors such as pedometers and activity tags worn by cows, identify increased restlessness and physical activity, which are secondary signs of estrus. These are potential novel sources of phenotypes objectively describing estrous behaviors in commercial herds to be studied further. Using activity tags on collars, Løvendahl and Chagunda (2009) defined the trait days to first high activity, representative of days to first detectable estrus, and reported heritability estimates of 0.12 to 0.18 and a repeatability of 0.18 . Other activityderived traits described by Løvendahl and Chagunda (2009) were period of increased activity and strength of estrus, which exhibited low heritabilities of 0.02 to 0.08 and 0.04 to 0.08 , respectively. Ismael et al. (2015) noted strong genetic correlations for interval from calving to 
first high activity with the traditional ICF measure (0.96). As well, moderate correlations for estrous duration and estrous strength with ICF were estimated $(-0.38$ and -0.50 , respectively; Ismael et al., 2015).

The heritability of activity-defined time to first estrus is greater than that of many traditional fertility traits and similar or slightly lower than heritability estimates described previously for C-LA based on milk P4 measures. An appealing feature of activity-based measurements is that the technology may be also used to define traits in heifers or dry animals as well as lactating cows, which would not be possible with milk P4 determined phenotypes. However, there are limitations to the use of activity monitor data in practice, such as measured units and undisclosed algorithms used by different systems, which may be unique depending on the manufacturer, different locations of the sensor on the cow, the need for calibration of systems even within the same manufacturer, and false positives (Løvendahl and Chagunda, 2009, 2010). If the number of herds utilizing activity monitors for reproduction management further increases, and data can be shared and centralized, activity data and the interval to first high activity may in the future be applicable to genetic evaluations for improved reproduction in dairy cows.

\section{Current Traits Combined with Improved Reporting}

Pregnancy Rate and Loss. Contemporary fertility traits use insemination records and either pregnancy check data or subsequent calving records, all of which need to be meticulously recorded, to confirm the conception date of a cow. Cows that successfully achieve pregnancy but suffer pregnancy loss are not always captured by these data. Differentiating between cows failing to establish pregnancy and those not maintaining pregnancy may be important for improving these 2 different factors that lead to reduced fertility and increased calving intervals. Pregnancy detection includes return to estrus, transrectal palpation of the uterus, and ultrasound scanning, or indirect detection through measures of hormones (e.g., P4) and pregnancy-associated proteins (Fricke et al., 2016). Milk pregnancy testing services are already being provided by some milk recording agencies (e.g., AgSource, United States; CanWest DHI and Valacta, Canada) through the measurement of pregnancy-associated glycoprotein levels in milk from routine DHI samples. Novel approaches to obtain pregnancy status from milk recording or inline milk sensing devices may help collect records on a larger proportion of the population, as both a confirmation and subsequent reconfirmations of pregnancy.
Although early embryonic loss may not currently be easily deduced, more extensive recording of pregnancy status could improve CR phenotypes and permit more widespread evaluation of this trait, along with providing phenotypes for embryonic or fetal loss. Using data from past reproductive trials in the United States, Bamber et al. (2009) looked at pregnancy loss and estimated a direct heritability for the embryo and maternal heritability for the dam of the embryo of approximately 0.49 and 0.17 , respectively. However, these values were based on small numbers of embryos. Carthy et al. (2015) determined embryo loss by identification of nonviable embryos through ultrasound examination. Using over 40,000 records, those authors found a low heritability of 0.02 and a repeatability of 0.66 . Additional investigation is required as to the genetics of pregnancy loss, especially because an embryonic or maternal reason for the failure is not clear.

Reproductive Management Strategies. New reproductive management tools, such as estrus synchronization and timed-AI protocols, are routinely employed in many dairy herds and have likely added to the observed improvements in reproduction (Wiltbank and Pursley, 2014). These technologies help overcome the difficulties of estrus detection, allow producers to choose a precise time for first and later AI without relying on waiting for cows to cycle and express estrus, which will hopefully be detected, and can aid in the breeding of anovular cows (Wiltbank and Pursley, 2014).

There is limited recording of the reproductive strategy used to accompany reproductive phenotypes. In genetic evaluations, if the use of timed AI is not coded or considered in analyses, the selection process might benefit cows that are merely good responders to synchronization protocols (Berry et al., 2016). Relatedly, it has been shown that there is a genetic element to the response of cows to superovulation protocols (Jaton et al., 2016), and therefore it is possible that similar conclusions could be found for synchronization programs. Goodling et al. (2005) attempted to examine the effects of reproductive synchronization on genetic parameter estimates for days to first breeding, DO, and pregnancy rate at $120 \mathrm{~d}$ postpartum, and found synchronization treatment produced heterogeneous variances. More data and a refined, uniform recording system to include documentation of reproductive synchronization is required to better examine the potential effect on fertility genetic evaluations. In the future, it is conceivable that there will be pressure to limit the use of synchronization protocols and producers will need to rely on estrus detection by visual means or automated technologies 
(Barkema et al., 2015). At such a time, it is important that the population of dairy cows has not been selected to be reliant on synchronization programs to achieve reproductive success.

The phenotypes currently used to genetically evaluate cow fertility have low heritability, but the large numbers of daughter records often give moderately to highly accurate breeding values, and large historical databases give accurate genomic predictions for young animals. Quantitative or binomial traits often are intended to measure incomes or costs rather than underlying biology. Therefore, using novel closer-to-biology variables with higher heritability coupled with the phenotypes already available could enhance genomic predictions for fertility traits, enable the refinement of the current selection indices, and increase genetic progress for fertility and reproduction traits in dairy cattle.

\section{CONCLUSIONS}

The improvement of reproductive efficiency of dairy cows is a preeminent goal within the industry today. The current catalog of phenotypes used in genetic evaluation includes interval and binary traits characterized by insemination and calving records. Such traits can be highly influenced by management decisions and combine the many intermediate mechanisms of reproduction into single overall traits. Generally, traditional fertility traits have low heritability estimates associated with them. Despite reproduction traits and various indicator traits being included in selection indices around the world, only modest improvements have been achieved. Novel reproduction phenotypes with greater heritability are currently being sought to facilitate selection for improved fertility. Progesterone-based phenotypes can more accurately detail the physiology of the cow, without the impeding bias of management. Selection could also be achievable for a cow's ability to display detectable estrus. Advancing technologies being used on-farm with in-line milk component measurements and activity monitoring sensors may be used to obtain phenotypes on large numbers of animals, while genomic selection could be used for accurate phenotypes collected on a smaller number of herds. As well, the phenotypes used may be enhanced by improved data quality, and recording of reproductive management strategies to ensure selection is toward animals capable of high fertility without intervention. To continue to genetically improve the reproductive capability of dairy cattle moving forward, it may be worthwhile to consider a greater contribution within national selection indices, despite potentially less overall profit to be gained, along with recording and investigating emerging trait opportuni- ties. In the future, novel reproductive traits could complement existing traits to further help genetic gains in reproduction, while also generating overall healthy, productive animals.

\section{ACKNOWLEDGMENTS}

Authors acknowledge partial funding by the DairyGen Council of the Canadian Dairy Network (Guelph, Ontario, Canada) and the Natural Sciences and Engineering Research Council of Canada (Ottawa, Ontario, Canada). Authors acknowledge partial funding also by Agriculture and Agri-Food Canada and by additional contributions from Dairy Farmers of Canada, the Canadian Dairy Network, and the Canadian Dairy Commission under the Agri-Science Clusters Initiative. We also gratefully acknowledge partial funding by the Efficient Dairy Genome Project, funded by Genome Canada (Ottawa, Canada), Genome Alberta (Calgary, Canada), Ontario Genomics (Toronto, Canada), Alberta Ministry of Agriculture (Edmonton, Canada), Ontario Ministry of Research and Innovation (Toronto, Canada), Ontario Ministry of Agriculture, Food and Rural Affairs (Guelph, Canada), Canadian Dairy Network (Guelph, Canada), GrowSafe Systems (Airdrie, Canada), Alberta Milk (Edmonton, Canada), Victoria Agriculture (Australia), Scotland's Rural College (Edinburgh, UK), USDA Agricultural Research Service (United States), Qualitas AG (Switzerland), and Aarhus University (Denmark).

\section{REFERENCES}

Agriculture and Horticulture Development Board. 2017. Profitable Lifetime Index (£PLI)-Holstein Breed. Accessed Mar. 14, 2018. http://dairy.ahdb.org.uk/technical-information/breeding -genetics/£pli/\#.WtS4zYjwZEZ.

Bamber, R. L., G. E. Shook, M. C. Wiltbank, J. E. P. Santos, and P. M. Fricke. 2009. Genetic parameters for anovulation and pregnancy loss in dairy cattle. J. Dairy Sci. 92:5739-5753.

Barkema, H. W., M. A. G. von Keyserlingk, J. P. Kastelic, T. J. G. M. Lam, C. Luby, J.-P. Roy, S. J. LeBlanc, G. P. Keefe, and D. F. Kelton. 2015. Invited review: Changes in the dairy industry affecting dairy cattle health and welfare. J. Dairy Sci. 98:7426-7445.

Bastin, C., S. Loker, N. Gengler, A. Sewalem, and F. Miglior. 2010. Genetic relationships between body condition score and reproduction traits in Canadian Holstein and Ayrshire first-parity cows. J. Dairy Sci. 93:2215-2228.

Bastin, C., L. Theron, A. Lainé, and N. Gengler. 2016. On the role of mid-infrared predicted phenotypes in fertility and health dairy breeding programs. J. Dairy Sci. 99:4080-4094.

Berry, D. P., F. Buckley, P. Dillon, R. D. Evans, M. Rath, and R. F. Veerkamp. 2003. Genetic relationships among body condition score, body weight, milk yield, and fertility in dairy cows. J. Dairy Sci. 86:2193-2204.

Berry, D. P., N. C. Friggens, M. Luzy, and J. R. Roche. 2016. Milk production and fertility in cattle. Annu. Rev. Anim. Biosci. 4:269-290.

Biffani, S., M. Marusi, F. Biscarini, and F. Canavesi. 2005. Developing a genetic evaluation for fertility using angularity and milk yield 
as correlated traits. Interbull Annu. Meet. Uppsala, Sweden, June 2-4, 2005 63-66.

Canadian Dairy Network. 2014a. The truth about low heritability traits. Accessed Jul. 2018. https://www.cdn.ca/articles.php.

Canadian Dairy Network. 2014b. Index weights: What you see is not what you get! Accessed Apr. 24, 2018. https://www.cdn.ca/ document.php?id=366.

Canadian Dairy Network. 2017. Genetic gain before and after genomics. Canadian Dairy Network Report. Accessed Jul. 2018. https:// www.cdn.ca/articles.php.

Canadian Dairy Network. 2018a. Lifetime Performance Index (LPI) Formula. Accessed Mar. 14, 2018. https://www.cdn.ca/document .php?id=443.

Canadian Dairy Network. 2018b. The fertility challenge. Accessed Jul. 2018. https://www.cdn.ca/articles.php.

Carthy, T. R., D. P. Ryan, A. M. Fitzgerald, R. D. Evans, and D. P. Berry. 2015. Genetic parameters of ovarian and uterine reproductive traits in dairy cows. J. Dairy Sci. 98:4095-4106.

Crowe, M. A., M. Hostens, and G. Opsomer. 2018. Reproductive management in dairy cows-The future. Ir. Vet. J. 71:1.

CRV. 2018. Statistical Indicators. Accessed Apr. 23, 2018. https:// www.crv4all-international.com/wp-content/uploads/2016/03/E -20-NVI.pdf.

Dairy New Zealand. 2009. Your Index. Your Animal Evaluation System. Accessed Mar. 14, 2018. https://www.dairynz.co.nz/media/ 581307/Your_Index_Your_AE_System.pdf.

Darwash, A. O., G. E. Lamming, and J. A. Woolliams. 1997a. Estimation of genetic variation in the interval from calving to postpartum ovulation of dairy cows. J. Dairy Sci. 80:1227-1234.

Darwash, A. O., G. E. Lamming, and J. A. Woolliams. 1997b. The phenotypic association between the interval to post-partum ovulation and traditional measures of fertility in dairy cattle. Anim. Sci. 65:9-16.

De Vries, A. 2006. Economic value of pregnancy in dairy cattle. J. Dairy Sci. 89:3876-3885.

Dechow, C. D., G. W. Rogers, and J. S. Clay. 2001. Heritabilities and correlations among body condition scores, production traits, and reproductive performance. J. Dairy Sci. 84:266-275.

Dematawewa, C. M. B., and P. J. Berger. 1997. Effect of dystocia on yield, fertility, and cow losses and an economic evaluation of dystocia scores for Holsteins. J. Dairy Sci. 80:754-761.

Dematawewa, C. M. B., and P. J. Berger. 1998. Genetic and phenotypic parameters for 305-day yield, fertility, and survival in Holsteins. J. Dairy Sci. 81:2700-2709.

Eaglen, S. A. E., M. P. Coffey, J. A. Woolliams, R. Mrode, and E. Wall. 2011. Phenotypic effects of calving ease on the subsequent fertility and milk production of dam and calf in UK HolsteinFriesian heifers. J. Dairy Sci. 94:5413-5423.

Fleming, A., E. A. Abdalla, C. Maltecca, and C. F. Baes. 2018. Invited Review: Reproductive and genomic technologies to optimize breeding strategies for genetic progress in dairy cattle. Arch. Anim. Breed. 61:43-57.

Fourichon, C., H. Seegers, and X. Malher. 2000. Effect of disease on reproduction in the dairy cow: A meta-analysis. Theriogenology 53:1729-1759.

Fricke, P. M., P. D. Carvalho, J. O. Giordano, A. Valenza, G. Lopes Jr, and M. C. Amundson. 2014. Expression and detection of estrus in dairy cows: The role of new technologies. Animal. 8s1:134-143.

Fricke, P. M., A. Ricci, J. O. Giordano, and P. D. Carvalho. 2016. Methods for and implementation of pregnancy diagnosis in dairy cows. Vet. Clin. North Am. Food Anim. Pract. 32:165-180.

Friggens, N. C., M. Bjerring, C. Ridder, S. Højsgaard, and T. Larsen. 2008. Improved detection of reproductive status in dairy cows using milk progesterone. Reprod. Domest. Anim. 43s2:113-121.

Gernand, E., and S. König. 2017. Genetic relationships among female fertility disorders, female fertility traits and productivity of Holstein dairy cows in the early lactation period. J. Anim. Breed. Genet. 134:353-363.

Goodling, R. C., G. E. Shook, K. A. Weigel, and N. R. Zwald. 2005. The effect of synchronization on genetic parameters of reproductive traits in dairy cattle. J. Dairy Sci. 88:2217-2225.
Gröhn, Y. T., and P. J. Rajala-Schultz. 2000. Epidemiology of reproductive performance in dairy cows. Anim. Reprod. Sci. 60-61:605614 .

Häggman, J., J. M. Christensen, E. A. Mäntysaari, and J. Juga. 2018. Genetic parameters for endocrine and traditional fertility traits, hyperketonemia and milk yield in dairy cattle. Animal. https://doi .org/10.1017/S1751731118001386.

Haugaard, K., and B. Heringstad. 2015. Short communication: Genetic parameters for fertility-related disorders in Norwegian Red. J. Dairy Sci. 98:1321-1324.

Interbull. 2018. Interbull: Description of National Genetic Evaluation Systems. Accessed Mar. 14, 2018. http://www.interbull.org/ib/ geforms.

Irish Cattle Breeding Federation. 2014. Understanding the Economic Breeding Index (EBI). Accessed Mar. 14, 2018. https://www .teagasc.ie/media/website/animals/dairy/Understanding_EBI _PTA_BV_Spring_2014.pdf.

Ismael, A., E. Strandberg, M. Kargo, A. Fogh, and P. Løvendahl. 2015 Estrus traits derived from activity measurements are heritable and closely related to the time from calving to first insemination. J. Dairy Sci. 98:3470-3477.

Jamrozik, J., J. Fatehi, G. J. Kistemaker, and L. R. Schaeffer. 2005. Estimates of genetic parameters for Canadian Holstein female reproduction traits. J. Dairy Sci. 88:2199-2208.

Jaton, C., A. Koeck, M. Sargolzaei, F. Malchiodi, C. A. Price, F. S. Schenkel, and F. Miglior. 2016. Genetic analysis of superovulatory response of Holstein cows in Canada. J. Dairy Sci. 99:3612-3623.

Kargo, M., L. Hjortø, M. Toivonen, J. A. Eriksson, G. P. Aamand, and J. Pedersen. 2014. Economic basis for the Nordic Total Merit Index. J. Dairy Sci. 97:7879-7888.

Koeck, A., F. Miglior, J. Jamrozik, D. F. Kelton, and F. S. Schenkel. 2014. Genetic relationships of fertility disorders with reproductive traits in Canadian Holsteins. 10th World Congress on Genetics Applied to Livestock Production. Vancouver, BC, Canada, August $17-22$.

Koeck, A., F. Miglior, D. F. Kelton, and F. S. Schenkel. 2012. Health recording in Canadian Holsteins: Data and genetic parameters. J. Dairy Sci. 95:4099-4108.

Launay, A. 2015. Institut de l'Elevage. Evaluation Génétique. Accessed Mar. 14, 2018. http://idele.fr/fileadmin/medias/Documents/ Nomenclatures/Nomenclature_BL_fr.pdf.

LeBlanc, S. 2010. Assessing the association of the level of milk production with reproductive performance in dairy cattle. J. Reprod. Dev. 56:S1-S7.

Loeffler, S. H., M. J. de Vries, and Y. H. Schukken. 1999. The effects of time of disease occurrence, milk yield, and body condition on fertility of dairy cows. J. Dairy Sci. 82:2589-2604.

Loker, S., C. Bastin, F. Miglior, A. Sewalem, L. R. Schaeffer, J. Jamrozik, V. Osborne, and A. Ali. 2013. Development of a genetic evaluation of body condition score for Canadian Holsteins. J. Dairy Sci. 96:3994-4004.

López de Maturana, E., A. Legarra, L. Varona, and E. Ugarte. 2007. Analysis of fertility and dystocia in Holsteins using recursive models to handle censored and categorical data. J. Dairy Sci. 90:20122024

Løvendahl, P., and M. G. G. Chagunda. 2009. Short communication: Genetic variation in estrus activity traits. J. Dairy Sci. 92:46834688.

Løvendahl, P., and M. G. G. Chagunda. 2010. On the use of physical activity monitoring for estrus detection in dairy cows. J. Dairy Sci. 93:249-259.

McParland, S., E. Kennedy, E. Lewis, S. G. Moore, B. McCarthy, M. O'Donovan, and D. P. Berry. 2015. Genetic parameters of dairy cow energy intake and body energy status predicted using midinfrared spectrometry of milk. J. Dairy Sci. 98:1310-1320.

Miglior, F. 2007. Genetic evaluation of reproductive performance in Canadian dairy cattle. Ital. J. Anim. Sci. 6s1:29-37.

Miglior, F., A. Fleming, F. Malchiodi, L. F. Brito, P. Martin, and C. F. Baes. 2017. A 100-year review: Identification and genetic selection of economically important traits in dairy cattle. J. Dairy Sci. 100:10251-10271. 
Miglior, F., B. L. Muir, and B. J. Van Doormaal. 2005. Selection indices in Holstein cattle of various countries. J. Dairy Sci. 88:12551263.

Mourocq. J. P. 2013. La Génétique: Au Cœur Des Résultats Économiques et Techniques Des Exploitations Laitières. Accessed Mar. 14, 2018. http://idele.fr/fileadmin/medias/Documents/SPACE_2013 _-_La_genetique__au_coeur_des_resultats_economiques_et _techniques_des_exploitations_laitieres_-_Pinard_d.pdf.

Müller, M. P., S. Rothammer, D. Seichter, I. Russ, D. Hinrichs, J. Tetens, G. Thaller, and I. Medugorac. 2017. Genome-wide mapping of 10 calving and fertility traits in Holstein dairy cattle with special regard to chromosome 18. J. Dairy Sci. 100:1987-2006.

Nayeri, S., M. Sargolzaei, M. K. Abo-Ismail, N. May, S. P. Miller, F. Schenkel, S. S. Moore, and P. Stothard. 2016. Genome-wide association for milk production and female fertility traits in Canadian dairy Holstein cattle. BMC Genet. 17:75-86.

Nordic Cattle Genetic Evaluation. 2015. Report on Economic Basis for a Nordic Total Merit Index. Accessed Mar. 14, 2018. http: //www.nordicebv.info/wp-content/uploads/2015/05/Report-on -Economic-Basis-for-a-Nordic-Total-Merit-Index.pdf.

Nordic Cattle Genetic Evaluation. 2017. NAV Routine Genetic Evaluation of Dairy Cattle-Data and Genetic Models. Accessed Mar. 14, 2018. http://www.nordicebv.info/wp-content/uploads/2015/ 05/Report-on-Economic-Basis-for-a-Nordic-Total-Merit-Index.pdf.

Nyman, S., K. Johansson, D. J. de Koning, D. P. Berry, R. F. Veerkamp, E. Wall, and B. Berglund. 2014. Genetic analysis of atypical progesterone profiles in Holstein-Friesian cows from experimental research herds. J. Dairy Sci. 97:7230-7239.

Ortega, M. S., A. C. Denicol, J. B. Cole, D. J. Null, and P. J. Hansen. 2016. Use of single nucleotide polymorphisms in candidate genes associated with daughter pregnancy rate for prediction of genetic merit for reproduction in Holstein cows. Anim. Genet. 47:288-297.

Palmer, M. A., G. Olmos, L. A. Boyle, and J. F. Mee. 2010. Estrus detection and estrus characteristics in housed and pastured HolsteinFriesian cows. Theriogenology 74:255-264.

Parker Gaddis, K. L., D. J. Null, and J. B. Cole. 2016. Explorations in genome-wide association studies and network analyses with dairy cattle fertility traits. J. Dairy Sci. 99:6420-6435.

Petersson, K.-J., B. Berglund, E. Strandberg, H. Gustafsson, A. P. F. Flint, J. A. Woolliams, and M. D. Royal. 2007. Genetic analysis of postpartum measures of luteal activity in dairy cows. J. Dairy Sci. 90:427-434.

Pryce, J. E., M. P. Coffey, and G. Simm. 2001. The relationship between body condition score and reproductive performance. J. Dairy Sci. 84:1508-1515.

Pryce, J. E., M. D. Royal, P. C. Garnsworthy, and I. L. Mao. 2004. Fertility in the high-producing dairy cow. Livest. Prod. Sci. $86: 125-135$.

Pryce, J. E., J. H. J. Van der Werf, M. Haile-Mariam, B. Malcolm, and M. E. Goddard. 2009. Updated index weights for the Australian Profit Ranking in dairy cattle. Proc. Assoc. Adv. Anim. Breed. Genet. 18:143-146.

Pryce, J. E., and R. F. Veerkamp. 2001. The incorporation of fertility indices in genetic improvement programmes. M. G. Diskin, ed. Pages 237-249 in Fertility in the High-Producing Dairy Cow, vol. 1. British Society of Animal Science, Edinburgh, Scotland.

Pryce, J. E., R. F. Veerkamp, R. Thompson, W. G. Hill, and G. Simm. 1997. Genetic aspects of common health disorders and measures of fertility traits in Holstein Friesian dairy cattle. Anim. Sci. 65:353360 .

Roche, J. R., N. C. Friggens, J. K. Kay, M. W. Fisher, K. J. Stafford, and D. P. Berry. 2009. Invited review: Body condition score and its association with dairy cow productivity, health, and welfare. J. Dairy Sci. 92:5769-5801.

Roelofs, J. B., F. J. C. M. van Eerdenburg, N. M. Soede, and B. Kemp. 2005. Various behavioral signs of estrous and their relationship with time of ovulation in dairy cattle. Theriogenology 63:1366-1377.

Roxström, A., E. Strandberg, B. Berglund, U. Emanuelson, and J. Philipsson. 2001a. Genetic and environmental correlations among female fertility traits and milk production in different parities of Swedish Red and White dairy cattle. Acta Agric. Scand. A Anim. Sci. 51:7-14.

Roxström, A., E. Strandberg, B. Berglund, U. Emanuelson, and J. Philipsson. 2001b. Genetic and environmental correlations among female fertility traits, and between the ability to show oestrus and milk production in dairy cattle. Acta Agric. Scand. A Anim. Sci. 51:192-199.

Royal, M., G. E. Mann, and A. P. Flint. 2000a. Strategies for reversing the trend towards subfertility in dairy cattle. Vet. J. 160:53-60.

Royal, M. D., A. O. Darwash, A. P. F. Flint, R. Webb, J. A. Woolliams, and G. E. Lamming. 2000b. Declining fertility in dairy cattle: Changes in traditional and endocrine parameters of fertility. Anim. Sci. 70:487-501.

Royal, M. D., A. P. F. Flint, and J. A. Woolliams. 2002. Genetic and phenotypic relationships among endocrine and traditional fertility traits and production traits in Holstein-Friesian dairy cows. J. Dairy Sci. 85:958-967.

Schaeffer, L. R. 1994. Multiple-country comparison of dairy sires. J. Dairy Sci. 77:2671-2678.

Sewalem, A., F. Miglior, G. J. Kistemaker, P. Sullivan, and B. J. Van Doormaal. 2008. Relationship between reproductive traits and functional longevity in Canadian dairy cattle. J. Dairy Sci. 91:1660-1668.

Sorg, D., M. Wensch-Dorendorf, K. Schöpke, G. Martin, R. Schafberg, N. Reinhold, S. Pache, and H. Swalve. 2017. Genetic analysis of new progesterone-based fertility traits in dairy cows measured onfarm. J. Dairy Sci. 100:8205-8219.

Tenghe, A. M. M., A. C. Bouwman, B. Berglund, E. Strandberg, J. Y. Blom, and R. F. Veerkamp. 2015. Estimating genetic parameters for fertility in dairy cows from in-line milk progesterone profiles. J. Dairy Sci. 98:5763-5773.

van der Lende, T., L. M. T. E. Kaal, R. M. G. Roelofs, R. F. Veerkamp, C. Schrooten, and H. Bovenhuis. 2004. Infrequent milk progesterone measurements in daughters enable bull selection for cow fertility. J. Dairy Sci. 87:3953-3957.

Van Doormaal, B. J., G. Kistemarker, J. Fatehi, F. Miglior, J. Jamrozik, and L. R. Schaeffer. 2004. Genetic evaluation of female fertility in Canadian dairy breeds. Proceedings of the 2004 Interbull Meeting, Sousse, Tunisia. 32:86-89.

VanRaden, P. M., J. B. Cole, and K. L. Parker Gaddis. 2018. Net Merit as a Measure of Lifetime Profit: 2018 Revision. Accessed Oct. 9, 2018. https://aipl.arsusda.gov/reference/nmcalc-2018.htm.

VanRaden, P. M., K. M. Olson, D. J. Null, and J. L. Hutchison. 2011. Harmful recessive effects on fertility detected by absence of homozygous haplotypes. J. Dairy Sci. 94:6153-6161.

VanRaden, P. M., A. H. Sanders, M. E. Tooker, R. H. Miller, and H. D. Norman. 2003. Daughter pregnancy rate evaluation of cow fertility. AIPL Research Report: DPR1 (11-02). Accessed Jul. 24, 2018. https://aipl.arsusda.gov/reference/fertility/DPR_rpt.htm.

VanRaden, P. M., A. H. Sanders, M. E. Tooker, R. H. Miller, H. D. Norman, M. T. Kuhn, and G. R. Wiggans. 2004. Development of a national genetic evaluation for cow fertility. J. Dairy Sci. 87:2285-2292.

VanRaden, P. M., M. E. Tooker, J. R. O'Connell, J. B. Cole, and D. M. Bickhart. 2017. Selecting sequence variants to improve genomic predictions for dairy cattle. Genet. Sel. Evol. 49:32-44.

Veerkamp, R. F., and B. Beerda. 2007. Genetics and genomics to improve fertility in high producing dairy cows. Theriogenology 68:S266-S273.

Veerkamp, R. F., E. P. C. Koenen, and G. De Jong. 2001. Genetic correlations among body condition score, yield, and fertility in first-parity cows estimated by random regression models. J. Dairy Sci. 84:2327-2335.

Veerkamp, R. F., J. K. Oldenbroek, H. J. Van Der Gaast, and J. H. J. Van Der Werf. 2000. Genetic correlation between days until start of luteal activity and milk yield, energy balance, and live weights. J. Dairy Sci. 83:577-583. 
Veerkamp, R. F., J. K. Oldenbroek, and T. van der Lende. 1998. The use of milk progesterone measurements for genetic improvement of fertility traits in dairy cattle. Interbull Bull. 18:62-67.

Vereinigte Informationssysteme Tierhaltung, V. 2018. Beschreibung Der Zuchtwertschätzung Für Milchleistungsmerkmale, Zellzahl, Exterieurmerkmale, Nutzungs- Dauer Und Zuchtleistungsmerkmale. Accessed Oct. 5, 2018. https://www.vit.de/fileadmin/DE/ Zuchtwertschaetzung/Zws_Bes_deu.pdf.

Viking Genetics. 2015. New Nordic Total Merit Index with continued focus on profitable dairy cows. Accessed Mar. 14, 2018. http:/ /www.nordicebv.info/wp-content/uploads/2015/04/New-Nordic -Total-Merit-index-with-continued-focus-on-profitable-dairy-cows .pdf.

Wall, E., S. Brotherstone, J. A. Woolliams, G. Banos, and M. P. Coffey. 2003. Genetic evaluation of fertility using direct and correlated traits. J. Dairy Sci. 86:4093-4102.
Walsh, S. W., E. J. Williams, and A. C. O. Evans. 2011. A review of causes of poor fertility in high milk producing dairy cows. Anim. Reprod. Sci. 123:127-138.

Wiggans, G. R., T. A. Cooper, P. M. VanRaden, and J. B. Cole. 2011. Technical note: Adjustment of traditional cow evaluations to improve accuracy of genomic predictions. J. Dairy Sci. 94:6188-6193.

Wiltbank, M. C., and J. R. Pursley. 2014. The cow as an induced ovulatory: Timed AI after synchronization of ovulation. Theriogenology 81:170-185.

Zwald, N. R., K. A. Weigel, Y. M. Chang, R. D. Welper, and J. S. Clay. 2004. Genetic selection for health traits using producer recorded data. I. Incidence rates, heritability estimates, and sire breeding values. J. Dairy Sci. 87:4287-4294. 